\title{
Influence of job design on employee performance in Musanze District, Rwanda.
}

\author{
Emmanuel SENZIRA ${ }^{1}$ and Dr. Gitahi Njenga, PhD $^{2}$ \\ ${ }^{1}$ School of Business and economic, Mount Kenya University, \\ Kigali, Rwanda \\ ${ }^{2}$ School of Business and economic, Mount Kenya University, \\ Kigali, Rwanda
}

\begin{abstract}
The purpose of this study was to examine the influence of organizational structure on employee performance in Musanze District, Rwanda. The study objective was to examine the influence of job design on employee performance. The research was grounded on scientific management theory. The researcher used descriptive research survey design with a target population was 86 employees. Census method was applied. The researcher used the questionnaire for data collection. Statistical Package of Social Science (SPSS) was used in data analysis process with descriptive methods being applied to facilitate conclusion. Results were presented by using the frequencies and Tables for findings interpretation. Hereafter the results showed that organizational structure influences the employee performance. A part of department of job design; 97.6\% accepted that they have a good coordination of their organization, they are good performer at their work, $87.2 \%$ of respondents accepted that their job design is very clear, significantly help them to accomplish their tasks with good results, 95.4\% accepted that in their institution, the job design for employees is favorable with clear responsibilities to everyone, $86 \%$ accepted that the methods used in their organization favor them to develop their skills and knowledge which improves their activities for gaining a high productivity. Pearson correlation results show $\mathrm{r}=0.883(88.3 \%)$ which was positive correlation and significant. Based on these results, the researcher recommended that other organizations especially in government to put in place good organizational structures with clear job design to strengthen and develop the employee performance. In conclusion, organization of Musanze District is sufficient on their inhabitants and employees. It means that well-structured system in organization
\end{abstract}

bring an effective performance, and organization becomes developed with good productivity. It recommends Musanze District to strength and improve their management by focusing on the organizational structure that result an effective performance in organization.

\section{Introduction}

Organization is a team or group of many people working together towards the same objectives and vision, have the common purpose to achieve with their performance on objectives where everyone has own tasks, duties and responsibilities. Organizational structure is based on organizing the positions, roles, levels of hierarchy, accountable ways and other mechanism used in organization, organizational structure is any establishment pattern of collaboration components of departments in organization, organizational structure shows the relationship among the participation of each units of organization, (Maduenyi\&Adunola, 2015).

A good organizational structure is the one key needed to construct the strong performance in employees, organizations have to be carefully on structure. The organizations are facing strong competitor and in order to achieve its goals and objectives, workers are the key factor of organizational success. Institutes put a lot of thought and effort to create the degree of employee satisfaction for getting performance in order to enhance their productivity and attain whole organizations objectives, (Gholamet al, 2016).

Organization has the duties to design a structure where it organize what they want to do, which positions they want to create, which level of qualification and enforce a cultural development in order to achieve normally goals and objectives. 
According Motowidlo, (2003), the performance is global of all those expected value of behaviors that each employee in organization give to their working environment and support their organization to get values of their activities. The workers who were considered as the high performers usually receive the opportunity of hiring earlier in the organization as compare to the low performers. According Pushpakumari, (2008), the success of every organization is based on the performance of employee's job, the achievement of high performance employees-need to work hard. Satisfied employees are motivated when they are motivated they will work hard and will be committed to the organization and will achieve the goals of the organization as well. According Sonnentag, (2005), the higher performance of workers, the higher the opportunity for getting the maximum productivity. For every organization, that wants to be productiveness in their activities, is necessary to use the methods that can facilitate to increase employees performance.

Job design is actually action or practice of job content and work strategies or methods that has been adopted in the job performance, exists the different types of job design; job enrichment, job enlargement, high performance design and others, job design is used to promote an organization to meet with its objectives effectively and stipulate the employee satisfaction in their activities, work design is the mechanism of work arrangement or rearrangement that has purpose to reduce/overcome the job dissatisfaction and barriers of employee to achieve on objectives, in this process organization raise strategies for getting high productivity and favor workers to be satisfied, (Memoona\&Kiran, 2013).

Job is any specific feature of a personal life and it occupies a lot of personal and professional time compared to any other quality of being active. To be satisfied is the pleasure felt after a need is completed. Other site would suppose a person is happy with job conditions when his/her expectations desires or requirements have been met. Job satisfaction describes how much extent an individual is pleased, comfortable or satisfied with his/her work. It is a pleasurable or positive-emotional state resulting from the appraisal of one's job or job experiences. In general organizations Job Satisfaction is a crucial subject of attention which is very considered by the higher authorities, policy-makers and top-executives in the reason this issue is related to many other significant and important-issues of organizations. Workers are the core-assets and key part of any administrations by that all explains of production are handled. As a human being this is human nature that workers are satisfied or dissatisfied what job they are assigned. This is very important objective of the administration that they should follow and put in

\section{ISSN 2455-6378}

practice such type of policies that can make an employee to satisfy that bring the performance with job which is assigned to them.

Nowier, (2009), contested that employee performance is determined by results that they produce and related to the goals/objectives achievement of organizations. Performance is considered as the actual conducting of activities to meet responsibilities according to standards. It is an explanation of what is done and how well it is done. According to Hazalinaet al, (2015), the level of organizational performance was shown by the degree of activities performed, the efficiency and effectiveness of policy guidelines and their shaping, laws implementation and administration ability to strength in field of executive power.

After all activities in organization the remuneration take place, as we know organization get performance by helped with many resources of materials, money and other important equipment. Organizations are operating in action and try to get competitiveness, they need to grow up strategically to hire and retain the competent employees on purpose of getting the efficient and effective productivity from human resource management. Remuneration is look like the total income of employee after completing his/her tasks and payment done according the agreements, (Buchan, 2000).

Remuneration take a great role as is a pillar of relationship between organization team (employers and employees), typically performance of employee depends on their needs and wants are available enough \& on time according contract agreement, this give satisfaction and performance to employee and bring a clear face to organization become competitive in environment, for employers, compensation decisions and regulations influence their cost of working business and competitive market and attract/retain qualified employees, (Barry \&Gerhart, 1995). Remuneration is a pay or reward given to employees for activities done. Remuneration contain; health care, wages, salary, transport allowance, pension schemes and others given to employees for satisfying them and get performance, (Ojeleye, 2017).

In this competition era, every organization tries to be the first for achieving on the goals and objectives completely that favor to attract the qualified employees. Employees are the organizational key factor of success, therefore organization puts a lot of thought and effort to learn the degree on how employees become satisfied in order to enhance their productivity and attain overall organizations objectives, (Muna, Zain \&Shaju, 2013). The researcher sought to investigate the influence of organizational structure on employees' performance in Musanze District, Rwanda. 


\section{Review of Literature}

\subsection{Organizational structure}

According to Ritika, (2019), the degree of effective performance of each employee occurred according to suitable organization structure; work behavior related to organization structure that are intentionally confirmed for accomplishing goals of organization. More discussions have taken time about organizational structure in the corporate world, the high achievement and satisfied of worker are fastened to organization structure. Structured procedure of organization coordinate and give the best ways to achieve on their aspiration and objectives, the work has to be categorized among employers and employees. Designed structure make reliable effective performance of organization and reinforce the staff, structure make a living the departments and its management.

Organization structure is the preparations of duties and tasks, interconnections of different departments of authority to get the targets. Structure means how job tasks are normally arranged grouped and controlled. And performance is mainly expression of employees positive attitudes strengthen their job. Organization has a duty to design a proper structure that must start with any ideas which help organization to achieve their objectives. Manager should support it in thoughts that job satisfaction intend to performance of employees for any ways find out their productivities and organization achieve on objectives for that proper structure raise optimum level of job satisfaction with performance.

According Maduenyi\&Adunola, (2015), in societies, organizational structure has more conditions to affect employee's performance. Anyhow the effects depend according various measurements of structure and job satisfactions. Greatly where organization authority is not centralized to entrust employee, the monetary and instrument are commonly diffused completely through each frequency of the organization structure could cause the low control and objectives could be disturbed as are the pillars of organization and every one focus on benefits of themselves rather than organization benefits. Structure of organization there will certainly enhance the act of realizing the aspects of performance announce value of profitability. In the other word ended centralized organizational structure that is high in path with the classical school of thought that stressed a strictly determined hierarchy-governed by good defined regulations and paths of authority would destroy initiatives and subsequently loss in performance. Anyhow, good working organization BGCA (based on group's collaboration in activities) is efficient of simplifying twice the use and coordination of resources in the organization and consequently augments job satisfaction and performance particularly in side of promotion and knowledge development.

\section{ISSN 2455-6378}

According Muhammed, (2014), at organization work place, the honest is very important, when employees are trustworthy and organization makes easy their employees by providing a trustworthy and organization create favorable environment, it will raise up the performance of organization and employees become performers. Mutual trust and trustworthy and teamwork in employment is the best tool that can result in the effective management and enhancement of employees' performance.

\subsection{Job Design}

Job design is the strategies applied on workplace to ensure that all equipment, requirements are effectively satisfied and available to accomplish the works and achieve on organizational goals, Buchanan, (1979). A manager in his/her hand has the duties for directing and setting the positions and responsibilities in organization with enough unique tools, (Adam, 2007). A good organization movements basically up righted from job design, when design done carefully, completely fitted with organization's goals activities performed very well. Designer (manager) sets up the duties and tasks in organization departments for the target of completing successfully their job tasks. He suggested the two group of elements (efficiency \& behavior elements) where efficiency elements present; particularization, labor division and standardization; for behavior elements present task identity, talent variety, task significance, self-government and feedback. The talent, task identity, task significance, selfgovernment, feedback, job security, and remuneration are crucial factors for employees' performance, (Adam, 2007).

There are some technics applied in management for job design, these technics are as follow; job enlargement, job rotation and job enrichment.

\subsubsection{Job Enlargement}

This technic used when employee's asks augmented, the goal of this technic is to encourage the employee interest in work place specifically enforcing job attraction through the different tasks employee performs. The aims of job enlargement is to design the activities of job in all factors which balance the organization interests with their employees' needs.

There are two parts of job enlargement; horizontal \& vertical enlargement. The horizontal enlargement, employee has much more tasks on her/his position. This done when tasks added on others and performed by employee at the same level of skills. The main objectives of these are develop the new skills to employee and reduce difficult tasks. The other hand vertical enlargement where employee get a power to control how tasks are to be executed, the main objectives are to raise up the status and employees 'satisfaction, (Memoona\&Kiran, 2013). 


\subsubsection{Job Rotation}

As the name say, it is a job design strategy permits the employee to quit on her/is position and occupy other position in conditional path. Job rotation is not done hazardously, some conditions are the following factors should be taken carefully; physical fitness needed on job position, gender, skills and knowledge, equipment and time for performing other duties, (Oparanma\&Nwaeke, 2015). This technic has more significant like development of skills, management improvement, employee 'performance, motivation, increase human capital and employees 'retention, (Jorgensen et al, 2007).

\subsubsection{Job Enrichment}

Job enrichment is a strategy used to motivate employee to perform the new best position from bottom to high level with new duties of coordinating, controlling, planning, directing his/her own performance with high level of knowledge and skills. Job enrichment characterized by knowing that tasks are good, diversity, to have a state of being able, and feedback, (Memoona\&Kiran, 2013).

\subsection{Scientific Management Theory}

In traditional management theory, scientific in common well-known in many organizations that constitutes four major objectives; friendship and leadership between workers and management to make sure that all are done in scientific way; scientific selection, training, development of employee knowledge for allowing them to do their own tasks scientifically; the science development of each element to replace the old one; department division between employees and management almost share equally and each department fits in conditions of organization, Accel, (2004). This theory emphasis the improvement and development of works through observation and analysis, financial incentives used to exceed the standard products and special successful in organization are; authority with bright depiction, duties, operations' plan separation, payment plan for employees, management by objection and duties related to qualification, (Jafar, et al, 2016).

\section{Materials and Methods}

Descriptive Research design was used, it provides a plan or framework for data collection and its analysis that was aimed at achieving the research objectives through experimental evidence. Quantitative design was applied. A descriptive survey design is considered to be most appropriate in this study because it consists the data collection methods that leads to the reliable findings of the study and structured questionnaire was used.

Target population is the study object that can be individual, group or organization according the research objectives. In this research, the target population was 86 employees from four administrative sectors (Muhoza, Cyuve, Muko and Nkotsi) in Musanze District.

Census method was used where all population was taken as sample size.

Table 3.1: Sample size determination

\begin{tabular}{lcc}
\hline Sectors & Administrative employees & Sample size \\
\hline Muhoza & 22 & 22 \\
Cyuve & 23 & 23 \\
Muko & 21 & 21 \\
Nkotsi & 20 & 20 \\
Total & $\mathbf{8 6}$ & $\mathbf{8 6}$ \\
\hline
\end{tabular}

Source: Musanze District (2020)

In procedure of data collection, the structured questionnaire was utilized to get information.

The research project used statistical analysis methods to present and summarize the findings, where frequencies and percentages were used. Descriptive statistics were used for making conclusion. Statistical Package of Social Science (SPSS) was used in data analysis process as an instrument.

\section{Results and Discussion}

\subsection{Demographic Characteristics of Respondents}

The first session of this research was demographic background, researcher analysis concerned with the demographic characteristics of respondents, these was included by the gender, age group, marital status, working experience, and education background of the respondents. 


\subsubsection{Gender of Respondents}

The researcher concerned on the gender distribution of respondents in order to get a picture of gender composition of respondents. The researcher wanted to found out whether the independent variables on the dependent variables depend upon by an individual gender status. The results were presented in the table 4.1 .

Table 4. 1: Gender

\begin{tabular}{rlrrrr}
\hline & & Frequency & \multicolumn{1}{c}{ Percent } & Valid Percent & Cumulative Percent \\
\hline \multirow{3}{*}{ Valid } & Man & 63 & 73.3 & 73.3 & 73.3 \\
& Woman & 23 & 26.7 & 26.7 & 100.0 \\
& Total & 86 & 100.0 & 100.0 & \\
\hline
\end{tabular}

Source: Primary data (2020)

Out of 86 respondents, a big number of them were men representing $73.3 \%$ and women were $26.7 \%$, all respondents responded this question.

\subsubsection{Age Group of Respondents}

In this research, the researcher wanted to know the respondents background information about the age group of them. The results were presented in the table 4.2.

Table 4. 2: Range of years

\begin{tabular}{rlrrrr}
\hline & Frequency & Percent & Valid Percent & $\begin{array}{c}\text { Cumulative } \\
\text { Percent }\end{array}$ \\
\hline \multirow{4}{*}{ Valid } & & 7 & 8.1 & 8.1 & 8.1 \\
& Below 30 years & 44 & 51.2 & 51.2 & 59.3 \\
& 30-40 years & 29 & 33.7 & 33.7 & 93.0 \\
& 41-50 years & 6 & 7.0 & 7.0 & 100.0 \\
& Above 50 years & 86 & 100.0 & 100.0 & \\
\hline
\end{tabular}

Source: Primary data (2020)

Out of 86 respondents, $8.1 \%$ were in the range old years below 30 years, $51.2 \%$ had range between 30 40 years, and $33.7 \%$ had the range of old years between $41-50$ years and $7 \%$ of respondents with the old years above 50 years. This indicates that the majority of employees had old years in the range of 30-40years, the ones who are still young and new employees in organization were below 30 old years. The respondents who were in the range 41-50 old

years and above 50 old years were the employees
who had a long time of working experience in organization administration.

\subsubsection{Marital Status of Respondents}

The researcher wanted to know the respondents marital status characteristics. The results were presented in the table 4.3 .

Table 4. 3: Marital status of respondents

\begin{tabular}{|c|c|c|c|c|c|}
\hline & & Frequency & Percent & Valid Percent & Cumulative Percent \\
\hline \multirow{3}{*}{ Valid } & Single & 12 & 14.0 & 14.0 & 14.0 \\
\hline & Married & 74 & 86.0 & 86.0 & 100.0 \\
\hline & Total & 86 & 100.0 & 100.0 & \\
\hline
\end{tabular}

while $86 \%$ were married. The majority of them were married with percentage of $86 \%$, means that a big number of employees were mature in working and decision making. They were exemplary in family management because there was no one who was divorced, as were working in republic administration

\subsubsection{Working Experience of Respondents}

Working experience in this research was considered as an important information of respondents' background. The results were presented in the table 4.4 . 
Table 4. 4: Working experience

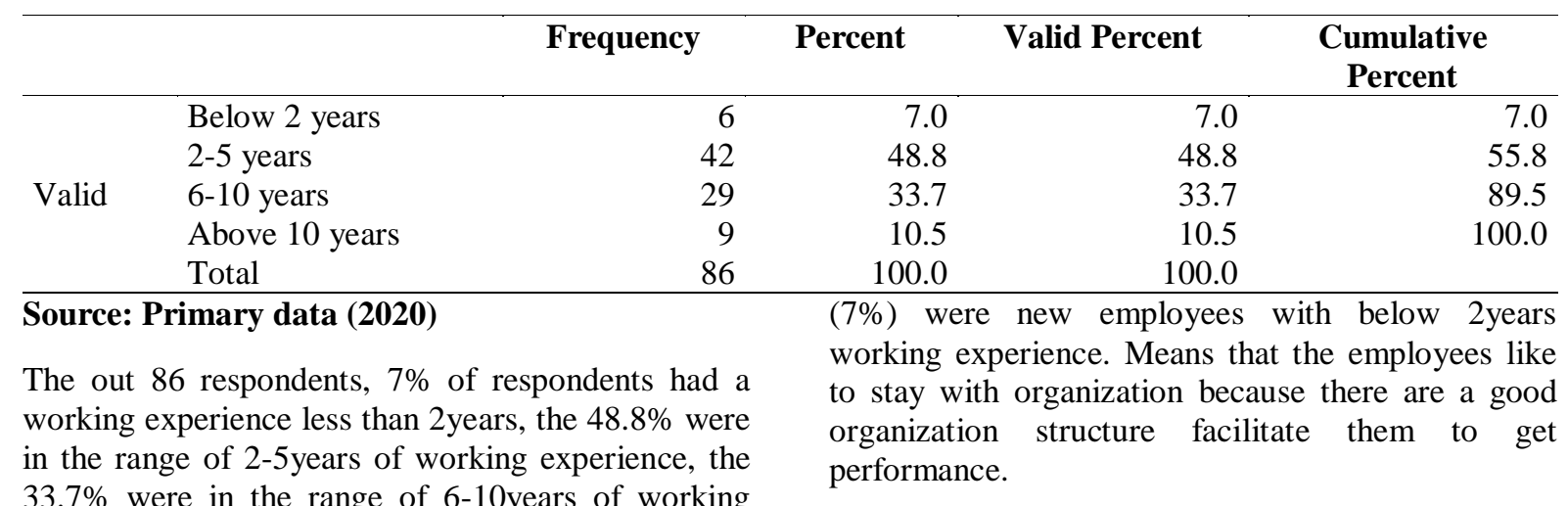
experience, the $10.5 \%$ had above 10 years of working experience. This presented that a big number of respondents had enough working experience because had worked long time with organization administration and presented that the less number

\subsubsection{Education Level of Respondents}

The education level of respondents was considered as an important information that can affect the independent variables on the dependent variables. The results were presented in the table 4.5.

Table 4. 5: Education level

\begin{tabular}{llrrrr}
\hline & Frequency & Percent & Valid Percent & Cumulative Percent \\
\hline \multirow{4}{*}{ Valid } & Secondary school A2 & 26 & 30.2 & 30.2 & 30.2 \\
& Diploma A1 & 18 & 20.9 & 20.9 & 51.2 \\
& Degree A0 & 41 & 47.7 & 47.7 & 98.8 \\
& Master & 1 & 1.2 & 1.2 & 100.0 \\
& Total & 86 & 100.0 & 100.0 & \\
\hline
\end{tabular}

Source: Primary data (2020)

Out of 86 respondents, the $30.2 \%$ of respondents had the secondary school A2, the $20.9 \%$ had Diploma A1, the $47.7 \%$ had Degree A0, and only $1.2 \%$ of respondents had a Master of the respondents of these four sectors (Muhoza, Cyuve, Muko and Nkotsi). The results presented that a big number of respondents (47.7\%) had a bachelor's degree (A0). The many respondents who had a degree founded in sector administration while a big number of someone who had a diploma (A1) and secondary school (A2) were the cell representatives and the small number of masters also founded in sector administration.

Findings of objective: The influence of job design on employee performance

The job design of cause has the effects on employee performance, the researcher wanted to determine the influence of job design on employee performance in Musanze District, Rwanda. The researcher focused on good coordination, job design is very clear, job design is favorable and job design methods. The results were presented in the following subthemes.

\subsubsection{Because of good coordination of organization, employee is a good performer at work.}

On this, researcher wanted to know that because of good coordination of organization, the employees were good performers at their work. The results were presented in the table 4.10 .

Table 4. 6: Because of good coordination of organization, employee is a good performer at work.

\begin{tabular}{llrrrr}
\hline & Frequency & Percent & Valid Percent & $\begin{array}{c}\text { Cumulative } \\
\text { Percent }\end{array}$ \\
\hline \multirow{4}{*}{ Valid } & & & 2.3 & 2.3 \\
& Unsure & 2 & 2.3 & 45.3 & 47.7 \\
& Accepted & 39 & 45.3 & 52.3 & 100.0 \\
& Highly Accepted & 45 & 52.3 & 100.0 & \\
\hline
\end{tabular}

Source: Primary data (2020) 
Out of the 86 respondents, the $2.3 \%$ of respondents were unsure that because of good coordination of organization employee was a good performer at work, the $45.3 \%$ accepted, and $52.3 \%$ highly accepted, there was nobody responded on unaccepted and on highly unaccepted. The results showed that employees like their organization coordination and they were performers because of good coordination in their organization, the big number of respondents highly accepted with $52.3 \%$. Only the few percentage of $2.3 \%$ were unsure, they were the ones who still new employees were trying to adopt the organization system. When the coordination is good

Table 4. 7: Our job design is very clear, this significantly helps employee to accomplish the tasks with good results. in an organization also employees become the good performers in their activities because the rules/regulations and conditions are clear on every one.

\subsubsection{The job design is very clear, this significantly helps employee to accomplish the tasks with good results.}

The researcher wanted to know that the job design was very clear, and significantly helps the employees to accomplish their tasks with good results. The findings were presented in the table 4.11.

\begin{tabular}{llrrrr}
\hline & Frequency & Percent & Valid Percent & $\begin{array}{c}\text { Cumulative } \\
\text { Percent }\end{array}$ \\
\hline \multirow{4}{*}{ Valid } & & & 4.7 & 4.7 \\
& Unaccepted & 4 & 4.7 & 8.1 & 12.8 \\
& Unsure & 7 & 8.1 & 53.5 & 66.3 \\
& Accepted & 46 & 53.5 & 33.7 & 100.0 \\
& Highly Accepted & 29 & 33.7 & 100.0 & \\
\hline
\end{tabular}

Source: Primary data (2020)

Out of the 86 contacted respondents, the $4.7 \%$ of respondents disagreed that their job design wasn't very clear, this significantly helped employee to accomplish the tasks with good results, the $8.1 \%$ were unsure, the $53.5 \%$ accepted and $33.7 \%$ of respondents highly accepted, there was nobody responded on highly unaccepted. This presented that job design was clear but still the improvement was needed because there was some who disagreed and others were unsure. As Ambrose, 2013 said, the Job design is the strategies applied on workplace to ensure that all equipment, requirements are effectively satisfied, available to accomplish the works and achieve on organizational goals. It was good the big number of respondents agreed so even the improvement was needed to make sure that all requirements related the job design are very clear.

\subsubsection{In institution, the job design of employees is favorable with clear responsibilities for everyone.}

The researcher wanted to know that in institution, the job design of employees was favorable with clear responsibilities for everyone. The findings were presented in the table 4.12 .

Table 4. 8: In institution, the job design of employees is favorable with clear responsibilities for everyone.

\begin{tabular}{llrrrr}
\hline & Frequency & Percent & Valid Percent & $\begin{array}{c}\text { Cumulative } \\
\text { Percent }\end{array}$ \\
\hline \multirow{3}{*}{ Valid } & & 1 & 1.2 & 1.2 & 1.2 \\
& Unaccepted & 3 & 3.5 & 3.5 & 4.7 \\
& Unsure & 49 & 57.0 & 57.0 & 61.6 \\
& Accepted & 33 & 38.4 & 38.4 & 100.0 \\
& Highly Accepted & 86 & 100.0 & 100.0 & \\
\hline
\end{tabular}

Source: Primary data (2020)

Out of the 86 respondents, the $1.2 \%$ of respondents disagreed that in institution, the job design of employees wasn't favorable with clear responsibilities for everyone, the $3.5 \%$ were unsure, the $57.0 \%$ accepted and $38.4 \%$ of respondents highly accepted, there was nobody responded on highly unaccepted. This presented that a big number of respondents agreed that in institution the job design of employees was favorable with clear responsibilities for everyone. The few number of respondents with unaccepted $(1.2 \%)$ and unsure $(3.5 \%)$ showed that the improvement in organization management is needed until every employee will get the favors with clear responsibilities which will give to very one to become a performer. 
4.2.2.4 The job design methods used in organization favor employee to develop the skills and knowledge which improves the activities for gaining a high productivity.

The researcher wanted to investigate that the job design methods used in organization favor employees to develop their skills and knowledge which improve their activities for gaining a high productivity. The findings were presented in the table 4.13 .

Table 4. 9: The job design methods used in organization favor employee to develop the skills and knowledge which improves the activities for gaining a high productivity.

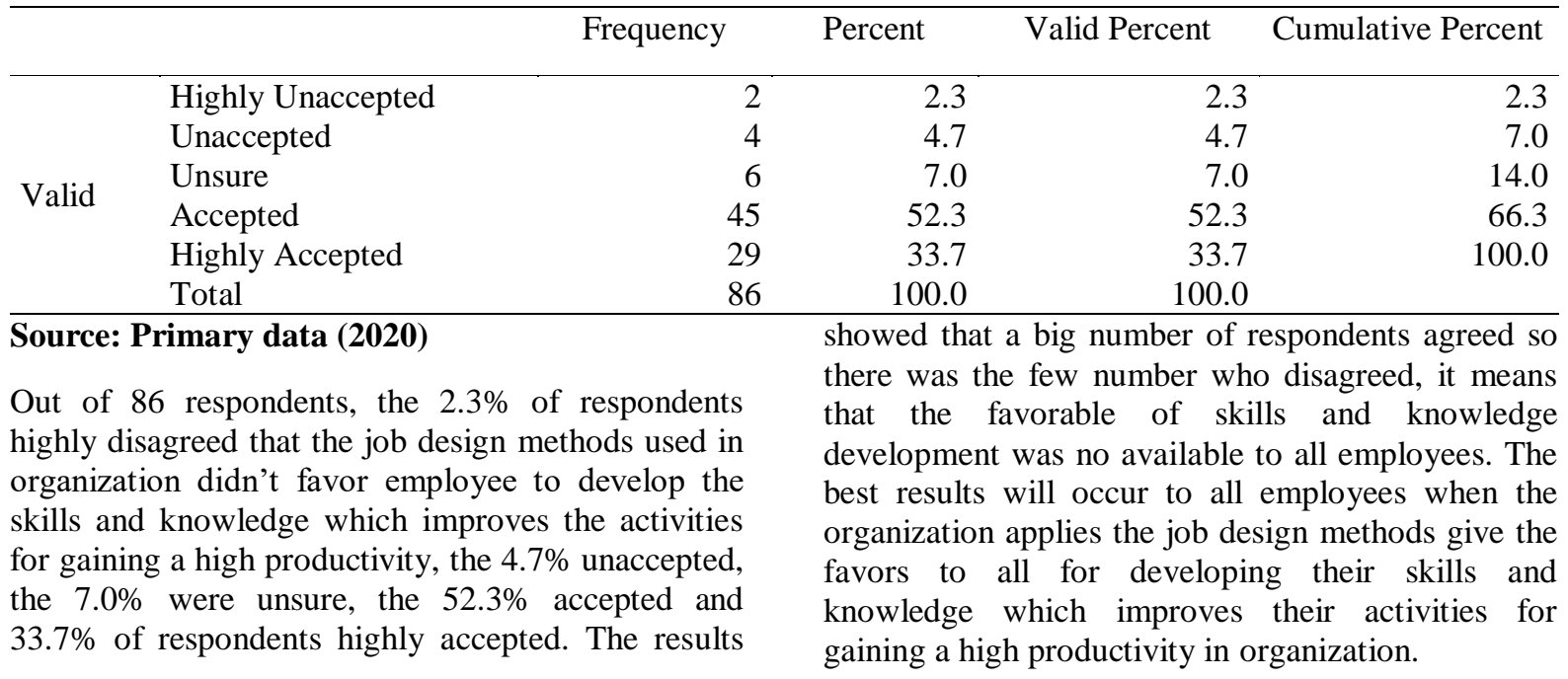

Correlation analysis

\begin{tabular}{llrrr}
\hline & & $\begin{array}{c}\text { Employee } \\
\text { performance }\end{array}$ & $\begin{array}{c}\text { Organizational } \\
\text { structure }\end{array}$ & Experience \\
\hline \multirow{3}{*}{ Employee performance } & Pearson Correlation & 1 & $.883^{* *}$ & .025 \\
& Sig. (2-tailed) & & .000 & .820 \\
& $\mathrm{~N}$ & 86 & 86 & 86 \\
Organizational structure & Pearson Correlation & $.883^{* * *}$ & 1 & .042 \\
& Sig. (2-tailed) & .000 & & .701 \\
& $\mathrm{~N}$ & 86 & 86 & 86 \\
Experience & Pearson Correlation & .025 & .042 & 1 \\
& Sig. (2-tailed) & .820 & .701 & \\
& $\mathrm{~N}$ & 86 & 86 & 86 \\
\hline
\end{tabular}

**. Correlation is significant at the 0.01 level (2-tailed).

Table 4.20 indicates the relationship between organizational structure, employee performance and experience of employees in Musanze District. A statistical package for social sciences (SPSS) software was used to find out a coefficient $r=0.883$. The pearson coefficient correlation is between -1 and 1. According the results, a pearson correlation is equal $\mathrm{r}=0.883(88.3 \%)$ shows there is a positive correlation and presents that there is a significant correlation between organization structure and employee performance in Musanze District.

\section{Conclusion}

The management of Musanze District is stable, organized with motivation that bring the moral in employees 'activities. Musanze District has a core management as shown by the results from employees' responses, it implement all activities based on the government policies, the human societies and employees in administration are working good that facilitate the administration in activities planning and implementation. An effective department structure is very important on employee performance, $84.025 \%$ of employees agreed that the organization was shaped in groups that allow employees to work in a harmony, it means that organization structure of Musanze District influence the employee performance in daily activities.

Musanze District management has a good job design favor their employees on performance, $91.55 \%$ of respondents showed that Because of good 
coordination of Musanze District organization, they were good performers at their work. In coordination Musanze district is strong that enables the employees to be performers. Musanze District enables to strongly motivate the citizens to develop in human being through the ideas, advices and salary given to employees, the $75.18 \%$ of respondents showed that they are developed in their life as organizational remuneration, salary is given on time. By the results, a pearson correlation is equal $\mathrm{r}=0.883(88.3 \%)$ shows there is a positive correlation and presents that there is a significant correlation between organization structure and employee performance in Musanze District. In general the organization of Musanze District is sufficient on their inhabitants and employees. It means that well-structured system in organization bring an effective performance, and organization becomes developed with good productivity.

\section{Acknowledgments}

I wish to acknowledge Dr. Dr. GitahiNjenga, (PhD) for his contribution to this work from the beginning up to its completion. I extend my acknowledgement to the authorities of Musanze District for their support and cooperation during this study.

\section{Reference}

[1] Accel. T, (2004), historical Perspective, Growth of scientific management; Hong Kong institute of technologies

[2] Adam. M. G, (2007), relational job design and the motivation to make a prosocial difference. University of Michigan, Academy of management Review, $32^{\text {th }}$ edition, P393-417

[3] Buchan. J, (2000), determining skills mix: practical guidelines for managers and health professionals. Queen Margaret University College.

[4] Buchanan, D. (1979), the development of job design theories and techniques, Praeger publishers, New York.

[5] Gholam. A. A, Mehrpour. M, Aghdas. N, (2016), organizational structure. $3^{\text {rd }}$ International conference on new challenges in management and organization: Organization and leadership, Dubai, UAE.

[6] Jafar. P, Shafeeq. H. Vazhathodi. A, Mohammed. B. M, (2016), scientific management theory: A critical review from Islamic theories of administration
ISSN 2455-6378

[7] Jorgensen. M, Kermit. D, Kotowski. S, Pranathi. A and Kari. D, (2007), characteristics of job rotation in the Midwest US manufacturing sector

[8] Maduenyi. S, Adunola O. O, (2015), impact of organizational structure on organizational performance; international conference on African development issues

[9] Memoona. Z, Kiran. R, (20113), job design and employee performance: the moderating role of employee psychological perception. European journal of business and management, Superior University, department of business administration, Lahore, Pakistan.

[10] Oparanma. O. A, Nwaeke. I. L, (2015), impacts of job rotations and employees' performances in manufacturing companies: Rivers State University of Science and Technology, Department of Management, Nigeria

[11]Ritika. S, (2016), impact of organization structure on job satisfaction, employee.

[12] Motowidle, S. J, (2003), job performance. Handbook of psychology: Industrial and organizational psychology.

[13] Pushpakumari, M. D, (2008), the impact of job satisfaction on job performance: empirical analysis.

[14] Sonnentag. S, (2005), performance concepts and performance theory. Universitat Mannheim.

[15] Nowier M, (2009), workplace environment and its impact on employee performance. Leadership and organization development journal

[16] Hazalina. M. S, Abudullah. O, Shahrul. N. S and Safizal. A, (2015), the relationship of work influence, sense of community and individual spirituality towards organizational performance.

[17] Manu. A. A, Zain. A. A, Shaju. G, (2013), job satisfaction and employee performance. International journal of advanced research in management and social science.

[18] Muhammed. A. A, (2014), the impact of organizational structure on employees' creativity. University of Punjab, Lahore, Pakistan. 